\title{
SEROPREVALENCE OF HEPATITIS C VIRUS ANTIBODIES AMONGST BLOOD DONORS IN AHMADU BELLO UNIVERSITY TEACHING HOSPITAL (ABUTH) KADUNA
}

\author{
ISA AH, HASSAN A. , MAMMAN, A.I , BABABDOKO, A.A. MUKTAR, H.M and AHMED, A.J \\ CORRESPONDANCE: ISA, A.H. Department of Haematology and Blood Transfusion, Ahmadu Bello University Teaching \\ Hospital (ABUTH) Zaria. Email: $\underline{\text { albarkatwo@yahoo.com Phone no: } 08054399861}$
}

\begin{abstract}
Background: Hepatitis $\mathrm{C}$ virus (HCV) is one of the most common transfusion transmissible infections hence the introduction of routine screening for its antibodies in blood donors in most blood banks.

Methods: This was a retrospective study in which the blood donor screening register for all intending donors were reviewed and analyzed.

Results: There were 4,731 potential donors with age range $20-41$ years. Eighty six $(1.8 \%)$ were sero-positive to HCV antibodies with a decreasing incidence over the period under review. The highest incidence was recorded the age group 31-40 years.
\end{abstract}

Aim: To determine the sero-prevalence of HCV among blood donors in ABUTH Kaduna.

Conclusion: HCV infection is not uncommon in our environment hence the need to emphasize it's routine screening among all potential donors.

\section{INTRODUCTION}

$\mathrm{HCV}$ is a single stranded RNA virus which until 1989 was named non A, non B hepatitis virus, was responsible for $80 \%$ of post transfusion hepatitis $(1,2,3)$. The modes of transmission are sexual intercourse, accidental inoculation (as in intravenous drug use, tattooing, acupuncture) with $\mathrm{HCV}$ - contaminated instruments, contact with infected body fluids and vertical transmission $(4,5,6)$. Sickle cell disease (SCD), haemophilia and haemodialysis are risk factors due to the need for repeated transfusion with

blood and blood products $(4,5)$. The seroprevalence of $\mathrm{HCV}$ antibodies ranges from $1.1 \%$ to $6.7 \%$ (7) in the West African sub-region.
Liver disease of variable course is the most common manifestation of $\mathrm{HCV}$ infection (4). Pegylated $\alpha$-interferon and/or Ribavirin are used for the treatment of $\mathrm{HCV}$ with variable outcomes (8).

$\mathrm{HCV}$ antibody screening was introduced in ABUTH blood bank in 1997 and since then its prevalence has not been determined among blood donors which this paper seeks to do.

Methods: This was a hospital- based retrospective study. It involved a review of the records of all intending blood donors on whom $\mathrm{HCV}$ antibody screening was done over a fouryear period, from January 2000 to December 2003. The donors were classified and analyzed 
based on age and seropositivity. HCV antibody screening was done with ELISA using Grand Medical Diagnostic (USA) Rapid Test kits.

Results: There were 4,731 blood donors over the study period with an average of 1, 184 donors per year. All donors were males with an age range of 20-41 years. The highest seroprevalence for $\mathrm{HCV}$ was in the age group 31-40 years (41\%). Eighty six (1.8\%) of donors were seropositive for HCV antibodies (Table 1).

Table 1: HCV Seropositivity among blood donors

\begin{tabular}{|c|c|c|c|}
\hline Year & NUMBER OF DONORS & SEROPOSITIVE DONORS & $(\%)$ \\
\hline 2000 & 914 & 19 & $(2)$ \\
\hline 2001 & 1,425 & 29 & $(2)$ \\
\hline 2002 & 970 & 16 & (1.7) \\
\hline 2003 & 1,422 & 22 & (1.5) \\
\hline TOTAL & 4,731 & 86 & (1.8) \\
\hline
\end{tabular}

Table 2: Age distribution of seropositive donors

\begin{tabular}{|c|c|c|c|c|c|}
\hline \multirow[t]{2}{*}{ AGE GROUP } & \multicolumn{4}{|c|}{ YEAR } & \multirow[b]{2}{*}{ TOTAL } \\
\hline & 2000 & 2001 & 2002 & 20003 & \\
\hline$\leq 20$ & 2 & 3 & - & - & $5(6 \%)$ \\
\hline $21-30$ & 7 & 13 & 8 & 3 & $31(36 \%)$ \\
\hline $31-40$ & 6 & 9 & 6 & 14 & $35(41 \%)$ \\
\hline$\geq 41$ & 4 & 4 & 2 & 5 & $15(17 \%)$ \\
\hline TOTAL & 19 & 29 & 16 & 22 & $86(100 \%)$ \\
\hline
\end{tabular}

Discussion: The routine screening of donors is essentially to ensure blood safety, particularly from transfusion transmissible infections such as HIV, HCV and HBV. The seroprevalence of $\mathrm{HCV}$ was $1.8 \%$ however there was a gradual decline over the study period (Table 1). This may be due to Media health education on the prevention of viral infections especially HIV which share same routes of transmission with $\mathrm{HCV}$.

The finding of $\mathrm{HCV}$ seroprevalence of $1.8 \%$ among blood donors in ABUTH Kaduna was remarkably lower than the finding by other workers from other parts of the country. Egah et 
al (3) reported a $\mathrm{HCV}$ seroprevalence of $6 \%$ in Jos. Chukwurah et al(8) in South Eastern Nigeria found a $\mathrm{HCV}$ seroprevalence of $7.6 \%$ while Ayolabi (10) et al (2006) in Lagos reported a $\mathrm{HCV}$ seroprevalence of $8.4 \%$ all among blood donors. Halim (10) et al (2000) in Benin reported a seroprevalence of $12.3 \%$ and Fasola (12) et al (2008) in Ibadan reported a seroprevalence of $3.9 \%$. The significantly lower prevalence in our study may be due to differences in the lifestyle of people in different regions of the country.

$\operatorname{Vardas}^{2}$ et al in Namibia reported a seroprevalence rate of $0.9 \%$ which is lower than our findings in Kaduna. Arthur (13) et al (1997) in Egypt reported 24.8\% HCV seroprevalence a value that is significantly higher than all the Nigerian reports. This may be attributed to method the method of HCV antibody determination (second generation enzyme immunoglobulin $\mathrm{G}$ antibody assay by Abbot). In 2003 Etard et al (7) reported a seroprevalence of $0.8 \%$ in Senegalese blood donors which is remarkably lower than our finding but comparative to the Namibian findings.

Conclusion: The seroprevelance of HCV was $1.8 \%$ and was more prevalent amongst the 31 $40 y r s$ age group. There is a need for mandatory screening for HCV antibodies in all blood banks and for continuous health education of the donor population in order to ensure the availability of safe blood.

\section{References:}

1. Brooks GF, Butel JS, Morse SA. Hepatitis Viruses. In: Jawetz,
Melnick and Adelberg's Medical Microbiology $22^{\text {nd }}$ Ed; McGaw-Hill USA, 2001; 406-407.

2. Vardas E, Sitas F, Seidel K, Casteling A, Sim J. Prevalence of hepatitis antibodies and genotypes in asymptomatic first time blood donors in Namibia. Bulletin of the World Health Organization. 1999; 77, 965-972

3. Egah DZ et al. Hepatitis $\mathrm{C}$ virus antibodies among blood donors in Jos Nigeria. Annals of African Medicine. 2004; 3, 35-37

4. Crawford JM. The Liver and the Billary Tract. In: Robins Pathologic Basis of Disease $6^{\text {th }}$ Ed; W.B. Saunders Philadelphia, 1999; 860.

5. Lesi OA, Kehinde MO. Hepatitis C virus in patients with sickle cell anaemia at the Lagos University Hospital. The Nigerian postgraduate medical journal. 2003; 10, 79-83.

6. Sharara AI, Hunt CM, Hamilton JD. Hepatitis C: update. Annals of Internal medicine. 1996; 125, 658668.

7. Etard J, Colbachini P, Dromigny J, Pierre-Gros-Claude J. Hepatitis C antibodies among blood donors, Senegal, 2001. Emerging infectious diseases. 2003; 9, 1492.

8. Chukwurah EF, Ogbodo SO, Obi GO. Seroprevalence of Hepatitis C Virus (HCV) among blood donors 
in South Eastern States of Nigera.

Biomedical research. 2005; 16, 133-135.

9. Ayolabi CI, Taiwo MA, Omilabu SA, Adebisi AO, Fatoba OM. Seroprevalence of hepatitis $\mathrm{C}$ virus among blood donors in Lagos, Nigeria. African journal of biotechnology. 2006; 5, 1944-1946.

10. Halim NKD, Ajayi OI. Risk factors and seroprevalence of hepatitis C antibodies in blood donors in Nigeria. East African medical journal. 2000; 77, 410-412.
11. National Digestive disease information clearinghouse (NDDIC) NIH. Chronic hepatitis C: Current disease management. 2006,704230 .

12. Fasola FA, Kotila TR, Akinyemi JO. Trends in transfusion-transmitted viral infections from 2001-2006 in Ibadan, Nigeria. Intervirology. 2008; 51, 427-431.

13. Arthur RR et al. Hepatitis C antibody prevalence in blood donors in different governorates in Egypt. Trans R Soc Trop Med Hyg. 1997; 91, 271-274. 